\title{
Correction to: The nexus between education and fertility in six European countries
}

\author{
Roberto Impicciatore ${ }^{1^{*}}$ and Francesca Tomatis ${ }^{2}$
}

The original article can be found online at https://doi.org/10.1186/ s41118-020-00104-4.

* Correspondence: roberto. impicciatore@unibo.it

${ }^{1}$ Alma Mater Studiorum - Università

di Bologna, Bologna, Italy

Full list of author information is

available at the end of the article
Correction to: Genus 76, 35 (2020)

https://doi.org/10.1186/s41118-020-00104-4

Following the original article's publication (Impicciatore \& Tomatis, 2020), the authors informed us that the following citation and reference were inadvertently included in the article:

- Keizer, Lindenberg and Steg 2008

- Keizer, K., Lindenberg, S., \& Steg, L. (2008). The spreading of disorder. Science, 322(5908), 1681-1685.

The reference and its in-text citation have already been removed from the original version of the article.

Author details

${ }^{1}$ Alma Mater Studiorum - Università di Bologna, Bologna, Italy. ${ }^{2}$ Università di Torino, Turin, Italy.

Published online: 14 December 2020

\section{Reference}

Impicciatore, R., \& Tomatis, F. (2020). The nexus between education and fertility in six European countries. Genus, 76, 35 https://doi.org/10.1186/s41118-020-00104-4.

(c) The Author(s). 2020 Open Access This article is licensed under a Creative Commons Attribution 4.0 International License, which permits use, sharing, adaptation, distribution and reproduction in any medium or format, as long as you give appropriate credit to the original author(s) and the source, provide a link to the Creative Commons licence, and indicate if changes were made. The images or other third party material in this article are included in the article's Creative Commons licence, unless indicated otherwise in a credit line to the material. If material is not included in the article's Creative Commons licence and your intended use is not permitted by statutory regulation or exceeds the permitted use, you will need to obtain permission directly from the copyright holder. To view a copy of this licence, visit http://creativecommons.org/licenses/by/4.0/. 